\title{
The Majority Legal Status of Women in Southern Africa: Implications for Women and Families
}

\author{
Mary P. Van Hook \\ University of Central Florida \\ Barbara N. Ngwenya \\ University of Michigan
}

\begin{abstract}
Women in many countries of southern Africa do not have majority status or have only recently gained this right. Majority status grants individuals adult legal status and the right to bring matters to court, own and administer property, have legal custody of children, and contract for marriage. This article summarizes the legal status of women in Botswana, Lesotho, South Africa, Swaziland, Zambia, and Zimbabwe. Lack of majority status contributes to the ongoing risk of poverty for women and makes them overly dependent on men. Compounding the situation in these countries is the presence of a dual legal system. Improving the situation of women and their families involves targeting changes in the legal system, influencing implementation of laws, educating women about their rights, and giving women needed support to seek their legal rights. The legal status of women must be viewed in the context of historical changes in the economic, educational, political, and cultural developments of society.
\end{abstract}

KEY WORDS: African families, African women, legal rights, poverty.

Mary P. Van Hook is Associate Professor, School of Social Work, University of Central Florida. The research for this paper was conducted during her previous faculty affiliation with the University of Michigan, School of Social Work. Her research interests include the impact of social change on women and families, rural mental health services, and health and mental health linkages. She received her Ph.D. from Rutgers University and her M.S.W. from the Columbia University School of Social Work.

Barbara N. Ngwenya is a doctoral student in Social Work and Anthropology and has a lectureship appointment in the Department of Social Work, University of Botswana. Her research interests are gender, work and family, culture and power, social transformations in rural and peri-urban communities, critical education, women and community politics, history of women, family and kinship issues, and community-based program development and evaluation. She received her M.S.W. from Dalhousie University, Halifax.

Journal of Family and Economic Issues, Vol. 17(2), Summer 1996

1996 Human Sciences Press, Inc. 


\section{Introduction}

Women face marginalization and severe poverty in Sub-Saharan Africa (Topouzis, 1990; United Nations Development Program [UNDP] 1991; World Resources Institute, 1994). In the context of these dire socioeconomic conditions, the legal majority status of women has emerged as an important social policy issue with wideranging implications for the social and economic welfare of women and their families (Kelso, 1993; Matlakala, 1989; McFadden, 1990, 1990-1991; Meena, 1991). Majority status grants persons adult legal status and with it the right to bring matters to court, to own and administer property, to have legal custody of children, and to contract for a marriage without parental consent. Yet a significant percentage of adult women in many countries in southern Africa is either currently denied these basic human rights or has been so until recently.

It is important to understand the impact of legal rights on women and families in the context of the family as a historically dynamic institution with ongoing interaction with economic, educational, religious, and other social systems; community institutions; and changes resulting from migration, urbanization, and technical developments. The World Resources Institute report (1994) indicates five areas of constraints that are especially relevant for women and their families in southern Africa: legal rights, economic, education, and reproductive health, and lack of political visibility. As discussed in this article, legal issues affect the resources and opportunities available to women and their families, and the legal system is also influenced by developments in these areas. The legal sphere includes not only specific laws and policies but also issues of implementation and access and the prevailing cultural attitudes that influence how people respond to and accept the current legal situation. Although laws provide the essential foundation, in practice women's legal rights depend more on their "general socioeconomic situation, their high rate of illiteracy, and on their ideological consciousness, strength, and financial wherewithal to challenge the community's views than on the law itself" (Maboreke, 1990, p. 5). The vast majority of poor women who live in the rural areas are doubly disadvantaged by these issues (Madisa, 1990; McFadden, 1990). Because legal rights provide the essential foundation for developments in these other areas, African women have targeted majority rights as an important issue for change while recognizing the need for efforts in other areas (Kelso, 1993; Matlakala, 1989; Meena 1991; Stewart \& Armstrong, 1990). 
This article presents a general overview of the issue of legal status for women in the countries of southern Africa by presenting the nature of the dual legal system in these countries, the historical context, the specific rights of women in several countries, the implications of these issues for women and their families, and some possible avenues for change. Although this discussion is limited to women in the countries of southern Africa, women in many other African countries face some of the barriers cited here (Connors, 1988).

\section{Dual Legal System}

The legal situation of women in contemporary southern Africa is complicated by the presence of a dual legal system, each part with its own set of laws and courts. The dual legal system includes the general laws (the Dutch-Roman or English legal systems) and the customary legal system. The general law consists of a set of codified laws with a court system based on the adversarial, legal counsel model. The customary legal system has a court system based on the authority of community leaders and does not involve representation by legal counsel. The customary legal system is available and potentially applicable for members of the indigenous groups, especially in the areas of private life.

Legally men and women have equal access to both systems; women, however, are more likely to turn to the customary legal system because it is more affordable. The low economic status of women makes it difficult for them to be represented by counsel, and legal aid is typically not available for the general legal system. Women and especially those who live in rural areas are also frequently more knowledgeable about the customary laws (Armstrong, 1992). As a result, the customary legal system has particular relevance for women, especially the large majority who are poor and live in the rural areas (Stewart \& Armstrong, 1990).

The dual system has its roots in the colonial period. During this period, conquest of indigenous Africans by Europeans meant imposition and establishment of their legal system (the English, Dutch-Roman), laws which were applied to settler subjects of European descent in the colonies (Stewart \& Armstrong, 1990). The colonial legal system undermined the rights of all the colonized people and also legitimized discrimination and subordination of women (Meena, 1991). The customary legal system is derived from the oral legal traditions 
of the various African precolonial states and chiefdoms. At the same time, "the selective and in many ways novel re-invention of customary law in Southern Africa by (male) African leaders together with the colonial authorities has been well documented" (e.g., Chanock, 1985; Comaroff \& Roberts, 1981; Kaganas \& Murray, 1994; Schmidt, 1990). Previously fluid customary laws became codified. Invariably the "invention and eventual codification of custom solidified fluid cultural and legal ideas and relationships into reproducible roles" (Mann \& Roberts, 1991, p. 4). Colonial meddling reinforced women's subordination while at the same time depriving them of the safeguards afforded in the precolonial way of life (Kaganas \& Murray, 1994). At the time of independence, laws were passed that made the general legal system applicable to all citizens of the country.

Customary laws were established originally by the colonial governments to fit preconceived notions of a traditional society based on a subsistence economy with self-sufficient joint family organizations (Comaroff \& Roberts, 1981; Connors, 1988; Mann \& Roberts, 1991). Historical changes in southern African society, including attenuation of the support available through the extended family, the increased individualization and organization of society around ownership of property, and a cash economy, have made the legal rights of women more important (Connors, 1988).

\section{Majority of Status of Women in Specific Countries}

As is evident in the following examples from the legal systems in several countries in southern Africa (Botswana, Lesotho, South Africa, Swaziland, Zambia, and Zimbabwe), the paternalism of the colonial powers and "traditional" African cultures have combined to limit the rights of women through both the specific laws and the surrounding social structures (Omolara Ogundipe, 1987; Schmidt, 1991). The following discussion is heavily indebted to the Women and the Law in Southern Africa Project (an organization dedicated to broad-based research, education, and social change pertaining to women in southern Africa). This discussion briefly describes the general legal situation regarding majority/minority status, marriage arrangements, and the right to own immovable property. These three elements are intricately interconnected in southern Africa. Other sources should be consulted for detailed information regarding the legal systems in these countries. 


\section{Botswana}

Traditional Tswana viewed women as "children of men" with very limited legal rights, even as adults (Schapera, 1938). In practice, single women above marriageable age enjoyed a measure of independence although theoretically they were under the guardianship of their fathers and were often allocated their own property which they could use and dispose of independently (Molokomme, 1991). For a detailed literature review see Ntete and Hermans (1992).

For married women, legal status, type of marriage, and property rights are interconnected. Currently couples can choose to marry under either the customary or general laws. Under customary law, married women do not have majority status. Husbands become their wives' guardians, and women, therefore, are dependent on their husbands to bring lawsuits and to enter into contracts. Husbands also control all the property of value, and wives have only rights of use. Although rights of use have typically been more important than ownership in traditional society, women are especially at risk when marriage ends by death or divorce. In the case of divorce, the husband frequently ends up with most of the valuable property as well as the children.

Majority status under general law is a complex matter. The Age of Majority Act grants single women over the age of twenty-one majority status, but the legal status of married women depends on their marital arrangement (in or out of community property). Women who marry out of community property (each person owns a portion of the property) retain their majority status. Cultural traditions that men own the major property items, however, pose further risk for women under this arrangement. As a result, women can be left destitute at the time of divorce even if they contributed substantially to the purchase and maintenance of the property.

Women who marry in common property (property held jointly by the couple) lose their right to majority status, which gives the husband sole authority to administer the property and to enter into contracts. Immovable property must be registered in the name of the husband so that he becomes the actual title holder and can deal with the property as he sees fit; the wife has no legal recourse.

Although the growing number of women who cohabit with men without marriage retain their right of majority status, customs and maintenance laws make these women very vulnerable. Customarily property of value is registered in the man's name. Maintenance laws 
require minimal support for the children and are poorly enforced. As a result, women are very dependent upon men and have little protection if their relationship terminates (Armstrong, 1992; Molokomme, 1990).

\section{Lesotho}

Under customary law, women are always minors under the guardianship of their fathers, their husbands, or the male heirs of their husbands. Adult unmarried women who can prove that they are emancipated can sometimes be approved to control their own property. Women have no right to inherit property. Several new legal policies (the Administration of Estates Act and the Intestate Succession Proclamation) grant women more rights in this area, but customary law policies regarding property make it very difficult for women to take advantage of these legal changes.

The general law in Lesotho grants single women majority status at age twenty-one. Marriages are arranged in common property unless the couple makes a special contractual arrangement before marriage to exclude the power of the man over the property. Under common property, the woman loses her right to majority status and must have her husband's permission to enter into contracts or employment, engage in any business arrangements, or take any legal action. Because husbands in Lesotho are frequently absent for long periods of time to work in the mines of South Africa, women can request the courts for authorization to engage in a legal transaction or to overrule the decisions of their husbands. This is an expensive and difficult process, and women are reluctant to take this step, especially if it might jeopardize their relationship with their husbands. Women are also dependent upon their husbands to further themselves economically in other ways, for example, they must obtain the consent of their husbands before applying for entry into an educational institution or applying for a scholarship (Seeiso, Kanono, Tsotsi, \& Monaphathi, 1990).

\section{South Africa}

The legal situation of women in South Africa is currently undergoing major shifts. Until recently under customary law, women passed from the guardianship of their fathers to that of their husbands and 
had limited contractual rights, and their children belonged to the fathers (Kaganas \& Murray, 1994). Even with marriage under the general law, for black couples (not whites) the husband retained power to administer the property of the couple, unless the couple specifically indicated otherwise (Connors, 1988). As equal rights and political power for blacks became a possibility, women began to assert their need for equal legal rights with men in South Africa (Eddings, 1994). The new interim constitution signed by President Nelson Mandela in January 1994 is founded on the principle of equality (including gender as well as race). As a result, women will have equal legal rights with men. Yet some traditional leaders are arguing that gender equality fails to reflect the principle of respect for diverse cultures. The challenge to gender equality is being fought by women's groups across political party lines (Kaganas \& Murray, 1994).

\section{Swaziland}

In addition to the restrictions associated with common property referred to previously, Swaziland women must also contend with the issue of marital power. Marital power under customary law is allencompassing, grants the husband full power over the wife, and reduces the wife to a status similar to that of a child in the household. Under general law, marital power is limited to the husband's power to represent the wife in legal proceedings and to administer property (Armstrong \& Nhlapo, 1985; Nhlapo, 1990; Standing, 1987).

The customary legal system is extremely strong in Swaziland. In fact, the Marriage Act governing general marriages requires that customary practices relating to marital power and property be in accordance with customary law unless the couple specifically opts out of this provision. Ignorance of these legal arrangements is widespread, and most couples do not realize the implications of their marital arrangement until long after they are married. Marriages conducted under customary laws grant the husband vast and wide-ranging marital power akin to that involved in guardianship. The patriarchal and patrilineal nature of Swazi society further disadvantages women because typically all property in a household is held in the name of the head of the household (the man) and access to land is acquired through a man. Women have limited access to wealth-generating property although recent legal interpretations are making it more possible even for married women to register land in their own names. How much effect these changes have depends greatly on the extent to 
which women and the area in which they live have become Westernized.

Couples who specifically opt out of the customary traditions can decide to marry either in common property (the wife has the right to half of the property, but her husband has the right to administer and make all decisions pertaining to it) or out of common property (the wife has majority rights to enter into contracts and administer property and power to make decisions about her own life) (Nhlapo, 1990).

\section{Zambia}

Zambians can choose to marry under the customary or the general law (the Marriage Act). Under customary law women are always minors in several areas, including marriage. The bridewealth (lobola) not only requires the parents' permission at the time of marriage but also makes it extremely difficult for a woman to dissolve the marriage without the consent of her parents. The husband has the right to select the place the family lives. Marriage under the act (general law) gives married women considerably more legal rights.

Unlike Botswana, Lesotho, and Swaziland, married women in Zambia can acquire, dispose of, or manage property in their own right under both customary and general law. Marriage under the customary law permits women to inherit from their parents but not from their husbands, even if they contributed to acquiring the property during their marriage. General law grants married women this right to inheritance. Both women married under customary or general law have equal rights with men in gaining custody of their children (Himonga, Turner, \& Beyani, 1990; Ndulo, 1987).

\section{Zimbabwe}

Several laws were passed in the early 1980 s, shortly after independence, which helped establish legal rights for women: the Customary Law and Primary Courts Act, which allows Africans to avail themselves of the general legal system; the Legal Age of Majority Act, which gives women of eighteen years and older majority status; the Labor Relations Act, which outlaws sexual discrimination in employment; and the Immovable Property Act, which seeks to eliminate sexual discrimination regarding the rights pertaining to immovable property.

Although before 1982 all women were perpetual minors, presently 
all unmarried adult women and married women who have not married in common property have majority status and full legal right to enter into contracts (including marriage), to acquire or dispose of or manage property, and to sue or be sued. Until the recent Matrimonial Causes Act, women were often left destitute at the time of divorce because the man tended to acquire the valuable property during marriage. The court can now allocate the property fairly, taking into consideration a variety of contributions to the marriage. Although the content of the law protects women, it means that the attitudes of members of the legal system are very important in assuring their actual rights. Laws depriving women of their majority status in common property marriages affect few families because this is a very rare form of marriage (Stewart, Ncube, Maboreke, \& Armstrong, 1990).

\section{Implications of Majority/Minority Status for Women}

As suggested in the preceding discussion, majority legal status for women in the countries of southern Africa is either a newly acquired right or remains a very tenuous or unavailable one for many women. Legal rights granted by customary laws are especially pertinent for women because the majority of women tend to live in rural areas where traditional community patterns are very strong. Choosing among these legal systems is also not as clear-cut as a description of the respective legal systems might imply. People often find it confusing to identify their rights under these two legal systems and to recognize which system would be the most advantageous in a particular situation (Maboreke, 1990; Mogwe, 1992). People also lack knowledge about their rights under the general law (Armstrong, 1992). Women's legal status profoundly affects the economic and social well-being of women and their families.

\section{Economic Issues and Majority Rights}

The legal status of women affects the economic condition of women and their families in several important ways. The following discussion emphasizes limitations in women's ability to acquire and control the means for generating income and women's dependence on men.

First, without majority rights women have very limited ability to acquire and control the property needed for generating income for themselves and their families. Because the majority of these women 
live in rural areas, issues pertaining to immovable property are especially important. Although rights to usage might be as important on a daily basis as ownership in many areas and in earlier years, women can be hurt in several ways in these increasingly cash-based economics. Without land or other forms of capital to serve as collateral for loans, women find it difficult to obtain the credit needed to purchase land, animals, and essential farming operations as well as the informal businesses in which they frequently engage (Adams, 1991; United Nations International Children's Emergency Fund [UNICEF], 1989, 1991; VanBrink, Mookodi, \& Dirasse, 1989). Competition for cash resources is intense, and women are disadvantaged vis-à-vis men. Because women are typically not employed in the formal sector (women constitute 25\% of the formal labor force in Zimbabwe, Botswana, Zambia, and Swaziland), access to funds to conduct farming or other informal businesses is especially important (Armstrong, 1992).

Women's poverty and lack of access to credit mires them into further poverty because they cannot afford to buy or lease animals for plowing their fields in a timely manner or for bringing their products to more distant markets. Consequently, they end up paying others to plow their land, and it is often not plowed at the time to take advantage of the rains, and being disadvantaged in marketing their products (Malatsi, 1995; Pankhurst, 1991; VanBrink et al., 1989). Furthermore, women find it difficult to avail themselves of new technologies that might save them valuable time and make their efforts more productive (Tandon, 1988).

This situation is further compounded because the economic situation in these countries has frequently required men to be absent from the rural areas to work in the mines or the cities. Colonial taxation, employment, and residential policies required men to migrate without their families to the mines and cities, and lack of economic development and opportunities in rural areas continues this pattern. As a result, women have assumed a major share of the responsibility for farming (Ivan-Smith, 1988; Tandon, 1988). Because of migration for employment or the effect of wars, as many as $46 \%$ of spouses are separated at any one time (Armstrong, 1992). Despite growing rhetoric for supporting women farmers; very little aid from either the United Nations or the United States is directed toward helping these women- $0.05 \%$ from the United Nations and 4\% from U.S. funds (Penna, Mahoney-Norris, McCarthy-Arnolds, Saunders, \& Campbell, 1990). 
Second, lack of majority rights makes women very dependent on men for their financial well-being. Laws and supporting customs that preclude women's ownership of substantial property in their own right or the right to an equal say in the administration of property make women extremely dependent on the goodwill, benign intentions, and wise judgment of their husbands. Women cannot legally protect their interest or that of their children against the husband's ill intentions or poor judgment. Although educated urban women who lose majority rights when they marry in common property can actually hold considerable sway in these decisions, this influence is informal and is not backed by the legal system. The informal sway of uneducated women in rural areas with strong paternalistic customs is likely to be considerably less (Setshwaelo \& Glickman, 1991).

\section{Family Relationships}

Lack of majority rights gives men enormous power in families, which contributes to a major power imbalance in the marital and family relationship. Furthermore, these laws tend to reflect the social customs of the society, which buttress the power legally granted to men (Meena, 1991). Laws preventing women from obtaining valuable property and failing to recognize and give credit to the different economic contributions of men and women to the relationship can make women extremely vulnerable. This combination can place women in a position in which they feel that they have no alternative but to accept any treatment in the marriage.

The poverty of women further contributes to this imbalance. The UNDP human development index (HDI) shows significant differences between women and men in both developed and developing countries. The report concludes that men fare better than women on almost every socioeconomic indicator (except life expectancy) and reveals a strong pattern of global gender discrimination. But in industrialized countries gender discrimination is typically detected through employment patterns (wages and availability of jobs) whereas in developing countries gender discrimination is broadly based and occurs in the areas of employment, education, health, nutrition, and religion (UNDP, 1991).

Even in countries that have recently established legal rights for women, the shadow of past discrimination continues to loom large and disadvantage women. Under the current Economic Structural Adjustment Programs (ESAP) mandated by the World Bank and the International Monetary Fund in several countries in southern Africa, 
women are especially likely to lose their jobs (Armstrong, 1992). Young people who manage to graduate from secondary school have difficulty finding employment (Nyanguru, 1991), and female students are doubly disadvantaged. Policies requiring school fees for secondary school have resulted in a recent drastic decline in secondary school enrollment of female students in Zimbabwe.

In both rural and urban areas job opportunities for women that pay wages adequate to support a family are limited. The vast majority of the poorly paid casual agricultural workers in Zimbabwe, for example, are women with children. These women and their children tend to be undernourished. Women also risk being separated from their children. In a recent study in rural Zimbabwe, some of the divorced women working as casual farm workers reported that they rarely saw their children although they were working to help pay the children's school fees. Under customary laws, the children were in the custody of their fathers (Adams, 1991).

The problem of violence toward women and children argues for the importance of a legal system that gives women some security outside of the marital family situation. Women are especially vulnerable because these countries do not have broadly based government support programs that women can rely on for income.

\section{Changes in the Legal System}

Efforts to remove legal barriers for women are taking two basic directions: changing the content and implementation of laws and enabling women to take advantage of their legal rights. Lobbying and advocacy efforts are currently addressing laws pertaining to majority rights, especially those that prevent women from controlling and administering property and allow husbands virtually unchecked ability to do so under the common property arrangement.

Part of this effort at social change involves educating women about their legal limitations and the negative consequences of these limitations for them and their families. To enlist women's support for change, workshops are being conducted to inform them about their legal rights and limitations. The Women and the Law Project in southern African has conducted numerous workshops at the community level which involved members of the community, interested community leaders, and persons knowledgeable about legal rights. A problem for these programs is that only about 60 to $65 \%$ of the women are literate. 
The Women's Action Group in Zimbabwe publishes a magazine (Speak Out) in the three major languages of the country and sells copies at a nominal rate at newsstands. In the context of debate in the country about the wisdom of majority rights for women, the magazine has published articles informing women of the issues involved.

It is also important to influence the views and attitudes of persons who carry out the work of the legal system. In addition to the considerable discretion typically granted the legal professionals involved in decisions, many of the new policies grant women potential rights do so by giving more discretionary power to these professionals. These professionals include judges, who are in a position to make very important decisions affecting women. These decisions may include such issues as deciding how much of a contribution a woman has made to a couple's resources at the time of a divorce or death (for example, in Zimbabwe under the Matrimonial Causes Act), if a woman can take independent action when her husband is absent (for example, in Lesotho), and which parent gets custody of the children.

Groups such as the Women and the Law Project are also identifying specific policies like majority status and citizenship rights which are critical for women and mobilizing efforts for legislative changes.

\section{Availing Women of Legal Rights}

Changes in the legal process are also being attempted by educating women and men about the legal arrangements open to them and ways they can avail themselves of these legal rights. The specific rights available to persons can be very complex, and decisions made early in life have long-standing implications. Although people generally may not think ahead to the consequences facing them in the future, it is even more problematic in these societies, which have a large proportion of women who are living in rural areas, are poor, and are illiterate or have a very limited education. These women are especially disadvantaged and are often not aware of their legal rights or able to make decisions about what legal system to use and which form of marriage to enter.

The Women in the Law in Southern Africa Project has been working with local women's and othèr community groups in rural and urban communities to help educate women about the nature of their rights. These workshops enlist the support and participation of the local leadership and community women's groups to help maintain the efforts initiated. If community women are to avail themselves of legal 
changes, they must be involved in the process of identifying which legal changes are important to them (Stewart \& Armstrong, 1990).

A recent study pertaining to maintenance laws conducted by the Women in the Law in Southern Africa Project revealed several major barriers which indicate the importance of providing more than education about the nature of the laws. Some of these barriers with broadbased implications include economic constraints (women cannot afford the transportation and other costs associated with dealing with the court system), indifferent attitudes of the court employees, women's sense of being intimidated by the court system, lack of enforcement of legal decisions, fear of losing their children if men were required to pay maintenance, and fear of witchcraft. As the Women in the Law Project concludes: "Programmers creating support groups to assist women through the court process or providing paralegals or others with basic legal information who can assist women through the legal process are more important than programmers supplying only general legal information" (Armstrong, 1992). These barriers also suggest the need to address the broad-based economic, educational, and cultural constraints that hinder women from taking advantage of their legal rights.

African women, and especially rural and poor women, typically have been disadvantaged in education, especially higher education. Improving educational opportunities for women has been targeted as an important issue for development generally (Penna et al., 1990). As women become educated, they will also be in a better position to understand, take advantage of, and question their legal situation. Unfortunately, social policies adopted as a result of economic social adjustment programs have resulted in a decrease in female education.

Although granting majority legal rights does not automatically change the poverty and marginization of women, it is an important and necessary step in this process. Making these changes involves many groups within the society and must recognize the connection between legal rights and economic, educational, and political developments.

\section{References}

Adams, J. (1991). Female wage labor in rural Zimbabwe. World Development, 19, 163177.

Armstrong, A. (1992). Struggling over scarce resources: Women and maintenance in 
southern Africa. Harare, Zimbabwe: University of Zimbabwe Press and Women and Law in Southern Africa Research Trust.

Armstrong, A., \& Nhlapo, R. (1985). Law and the other sex: The legal position of women in Swaziland. Mababane, Swaziland: Websters.

Chanock, M. (1985). Law, custom and social order: The colonial experience in Malawi and Zambia. Cambridge: Cambridge University Press.

Comaroff, J., \& Roberts, S. (1981). Rules and process: The cultural logic of dispute in an African context. Chicago: University of Chicago Press.

Connors, J. (1988). The legal position of women. In E. Ivan-Smith, N. Tandon, \& J. Connors (Eds.), Women in Sub-Saharan Africa (pp. 12-15). London: Minority Rights Group.

Eddings, J. (1994). Fighting the next battle. U.S. News and World Report, 116(12), 53-54.

Himonga, C., Turner, K., \& Beyani, C. (1990). An outline of the legal status of women in Zambia. In J. Stewart \& A. Armstrong (Eds.), The legal situation of women in Southern Africa (Vol. 2, pp. 139-164). Harare, Zimbabwe: University of Zimbabwe Press.

Ivan-Smith, E. (1988). Women's health and education. In E. Ivan-Smith, N. Tandon, \& J. Connors (Eds.), Women in Sub-Saharan Africa (pp. 10-11). London: Minority Rights Group.

Kaganas, F., \& Murray, C. (1994). The contest between culture and gender equality under South Africa's interim constitution. Journal of Law and Society, 21, 409433.

Kelso, B. (1993). The fight for equal rights. Africa Report, 38(5), 35-39.

Maboreke, M. (1990). Introducing women's law. In J. Stewart \& A. Armstrong (Eds.), The legal situation of women in Southern Africa (Vol. 2, pp. 1-6). Harare, Zimbabwe: University of Zimbabwe Press.

Madisa, M. (1990). The status of women in Botswana. Southern Africa Political and Economic Monthly, 4(1), 37-39.

Malatsi, M. (1995). Possibilities for cushioning the adverse effects of these structural adjustment programs in vulnerable women in Zambia. In G. Thomas-Emeagwali, Women pay the price: Structural adjustment in Africa and the Caribbean (pp. 121132). Trenton: Africa World Press.

Mann, K., \& Roberts, R. (1991). Law in colonial Africa. Portsmouth, NH: Heinemann.

Matlakala, D. (1989). Women and the law in Botswana: Action strategies. Gabaronne: Women's Affairs Unit/Emang Basadi.

McFadden, P. (1990, August). The condition of women in southern Africa: Challenges for the 1990's. Southern Africa Political and Economic Monthly, 3(11), 3-9.

McFadden, P. (1990-1991). The impact of gender analysis on African development. Southern Africa Political and Economic Monthly, 4(3/4), 39-42.

Meena, R. (1991). Conceptual issues of gender in southern Africa. Southern Africa Poltical and Economic Monthly, 4(10), 38-43.

Mogwe, A. (1992 July 26). Women and the Law in Southern Africa Project. Personal conversation.

Molokomme, A. (1990). Women's law in Botswana: Law and research needs. In J. Stewart \& A. Armstrong (Eds.), The legal situation of women in southern Africa (Vol. 2, pp. 7-46). Harare, Zimbabwe: University of Zimbabwe Press.

Molokomme, A. (1991). Children of the fence: The maintenance of extramarital children under law and practice in Botswana (Research report 46). Leiden, The Netherlands: University of Leiden, Center for African Studies.

Ndulo, M. (Ed). (1987). Law in Zambia. Nairobi: East Africa Publishing House.

Nhlapo, R. (1990). The legal situation of women in Swaziland and some thoughts on research. In J. Stewart \& A. Armstrong (Eds.), The legal situation of women in southern Africa (Vol. 2, pp. 97-138). Harare, Zimbabwe: University of Zimbabwe Press. 
Ntete, D., \& Hermans, J. (1992). Men's attitudes toward women in Botswana. Gaborone, Botswana: University of Botswana, National Institute for Research and Documentation.

Nyanguru, N. (1991). The social cost of the economic reforms and structural adjustment (in Zimbabwe). In Nigel Hall (Ed.), The social implications of structural adjustment programs in Africa (pp. 97-138). Harare, Zimbabwe: University of Zimbabwe, School of Social Work.

Omolara Ogundipe, L. (1987). African women, culture and another development. Presence Africaine, 141, 123-139.

Pankhurst, D. (1991). Constraints and incentives in "successful" Zimbabwean peasant agriculture: The interaction between gender and class. Journal of Southern Africa Studies, 17, 611-632.

Penna, D., Mahoney-Norris, K., McCarthy-Arnolds, E., Saunders, T., \& Campbell, P. (1990). A woman's right to political participation in Africa. Africa Today/Africa Rights Monitor, 37(1), 49-64.

Schapera, I. (1938). A handbook of Tswana law and custom. London: Oxford University Press.

Schmidt, E. (1990). Negotiated spaces and contested terrain: Men, women, and the law in colonial Zimbabwe, 1890-1939. Journal of Southern African Studies, 16, 622646.

Schmidt, E. (1991). Patriarchy, capitalism, and the colonial state in Zimbabwe. Signs, $16,732-756$.

Seeiso, S., Kanono, L., Tsotsi, M., \& Monaphathi, T. (1990). The legal situation of women in Lesotho. In J. Stewart \& A. Armstrong (Eds.), The legal situation of women in southern Africa (Vol. 2, pp. 47-74). Harare, Zimbabwe: University of Zimbabwe Press.

Setshwaelo, N., \& Glickman, M. (1991, July). Women in development. Gabaronne, Botswana: University of Botswana.

Standing, H. (1987). Gender relations and social transformation in Swaziland: Some comments on future research possibilities. In M. Neocosmos (Ed.), Social relations in rural Swaziland: Critical analyses. Kwalusenin, Swaziland: University of Swaziland.

Stewart, J., \& Armstrong, A. (1990). The legal situation of women in southern Africa. Harare, Zimbabwe: University of Zimbabwe Press.

Stewart, J., Ncube, W., Maboreke, M., \& Armstrong, A. (1990). The legal situation of women in Zimbabwe. In J. Stewart \& A. Armstrong (Eds.), The legal situation of women in southern Africa (Vol. 2, pp. 169-222). Harare, Zimbabwe: University of Zimbabwe Press.

Tandon, N. (1988). Women in rural areas. In E. Ivan-Smith, N. Tandon, \& J. Connors (Eds.), Women in Sub-Saharan Africa (pp. 7-10). London: Minority Rights Group.

Topouzis, D. (1990, July-August). The feminization of poverty. Africa Report, 35(3), 6063.

UNICEF (1989). Children, women and development in Botswana: A situation analysis. Gaboronne, Botswana: Botswana Govt. Printing office.

UNICEF (1991). The situation analysis of women and children in Lesotho. Maseru, Lesotho: Ministry of Planning and UNICEF.

United Nations Development Program (UNDP). (1991). Human development report 1991. New York: Oxford University Press.

VanBrink, E., Mookodi, G, \& Dirasse, L. (1989). Report on the gender responsive planning workshop for the Chobe District. Gabaronne, Botswana: Women's Affairs Unit.

World Resources Institute (1994). World resources: A guide to the global environment. New York: Oxford University Press. 